\title{
There Is No Accounting For Fannie Mae
}

RamMohan R. Yallapragada, (E-mail: ryallapragada@gmail.com), Fayetteville State University

\begin{abstract}
The Federal National Mortgage Association (FNMA, Fannie Mae), was created in 1938, as a part of the New Deal. In 2003, regulators discovered serious accounting problems that may cost Fannie Mae several billion dollars in losses. In 2003, the Office of Federal Housing Enterprises Oversight (OFHEO) investigated Fannie Mae and found a culture of corruption, arrogance, and pervasive accounting violations in the company. Executives at Fannie Mae cooked books to pocket an extra twenty-seven million dollars in bonuses. This paper presents the accounting improprieties at Fannie Mae and the consequences that followed its investigation.
\end{abstract}

\section{INTRODUCTION}

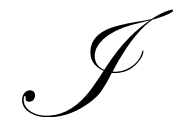

n 2001 and 2002, United States (US) corporate world was rocked to its roots by huge accounting scandals resulting in billions of dollars of financial restatements, severe losses to investors, reputation problems for the business entities and jail terms for senior management in Enron, WorldCom and other major US corporations. Congress enacted the Sabanes-Oxley Act (Sarbox) in a hurry, strengthening the regulatory authority and the oversight functions of several federal agencies (Falcon, Jr., 2005). These scandals, the court trials, and the passage of Sarbox Act received wide media coverage and national and international attention during $2002-2004$.

During the same time, a little-known federal regulatory agency, the Office of Federal Housing Enterprise Oversight (OFHEO), was investigating accounting failures at Fannie Mae and Freddie Mac, known as Government Sponsored Enterprises (GSEs), resulting in the largest financial restatements in history - totaling more than \$20 billion, dwarfing the combined restatements of both Enron and Worldcom (Falcon, Jr., 2005). OFHEO's investigation received far less attention than the scandals at Enron and WorldCom but it uncovered a culture of corruption at Fannie Mae that rivaled and surpassed the most serious corporate scandals of recent years. As York (2006) points out, "the main players in this case are Washington insiders - some of them prominent veterans of the Clinton administration and the scandal's effects could ripple through Congress for several years."

\section{HISTORICAL BACKGROUND}

The Federal National Mortgage Association and the Federal Home Loan Mortgage Corporation (Popularly known as Fannie Mae and Freddie Mac, respectively) are the two extremely large companies that are the main stay of the residential mortgage finance system of the US. Fannie Mae and Freddie Mac are the fourth and the fifth largest companies in the US as measured by assets (White, 2005). They issue and guarantee mortgage-backed securities and also invest directly in residential mortgage assets. These assets are funded predominantly by debt. These two companies are owned by shareholders and their stock is traded on the New York Stock Exchange (NYSE). But they are not ordinary companies. As White (2005) states, they have some special connections with the federal government that renders them quite unique:

- They were created by Acts of Congress and thus hold special federal charters, whereas, all other corporations hold charters granted by states.

- $\quad$ They are exempt from all state and local income taxes.

- $\quad$ They can use Federal Reserve as their fiscal agent. 
- $\quad$ Their debt is eligible for use as collateral for public deposits, for purchase by the Federal Reserve in open market operations and for unlimited investment commercial banks and Savings \& Loan Associations.

- $\quad$ Their securities are exempt from Securities and Exchange Commission's (SEC) registration and reporting requirements.

- $\quad$ Their securities are exempt from the provisions of many state investor protection laws.

- $\quad$ They are exempt from bankruptcy law and no receivership provisions apply to them. Thus, in case of financial difficulty, only the Congress could resolve any claims situation (White, 2005).

These special features of the two companies have conferred an aura of a "Halo" around them. The financial markets, therefore, have come to believe that the federal government would step in to bail them out in case of any financial difficulty, even though their charters and each security they issue state explicitly that these companies are not obligations of the federal government (White, 2005).

Frame and White (2005) give an interesting description of these companies' special situation wherein their anomalous legal status enabled them to have grown into enormous financial institutions, with combined total assets of over $\$ 1.8$ trillion in 2003. According to Carnell (2004), "these two companies' growth is at least partially a consequence of a 'double game' that they play. They tell Congress and the news media, 'Don't worry, the government is NOT on the hook' - and then turn around and tell Wall Street, 'Don't worry, the government IS on the hook."

\section{FANNIE MAE}

The National Housing Act of 1934 created the Federal Housing Authority (FHA) and also provided for chartering national mortgage associations as entities within the federal government. The only such association ever formed was the National Mortgage Association of Washington which eventually became the Federal National Mortgage Association, Fannie Mae (Frame and White, 2005). Over the years, its main business was to issue debt and use the proceeds to buy mortgages from lenders who could use the funds for new mortgages. It was originally a government agency, but it became private in 1968, with an avowed mission of, "increasing the availability and affordability of homeownership for low, moderate and middle-income Americans." (York, 2006). But, Fannie Mae is not just any private corporation. It is established in law and has all the afore-mentioned special features. It can borrow money at a lower rate than anyone else except the federal government itself. All these special features created a notion of "Implied Guarantee" from the feds and a feeling in the market that its bonds are next best things to the Treasury Bills.

In 1980, Fannie Mae went a step further creating a new product. It began buying mortgages and bundled them up for sale to investors as mortgage backed securities. The move was beneficial for both Fannie Mae and for the housing market as well. However, in the1990s, Fannie Mae took a much riskier move. It used its huge borrowing power to buy mortgages and hold them, making a profit from the difference between the low rate it paid to borrow money and the higher interest rate it received on the mortgages (York, 2006). Fannie Mae thus began abandoning its avowed mission and started to concentrate on profits. It also increased its exposure to interest-rate risks.

\section{ACCOUTING PROBLEMS AT FANNIE MAE}

In 2003, Freddie Mac was investigated by OFHEO for accounting scandals that resulted in huge financial restatements and a wholesale change in its top management. In the wake of the accounting fraud at Freddie Mac, OFHEO began investigating Fannie Mae. After an eight-month investigation, OFHEO released a 200-page report in September 2004. The investigation covered the years 1998 to 2004, during which period Fannie Mae was headed by former Clinton budget director Frank Raines, a former Rhodes scholar. In the early 1990s, Raines had been a top official at Fannie before he left to join the Clinton administration. Raines returned to Fannie as the Chief Executive Officer in 1998. Fannie had over 5,000 employees and his top management included former Clinton Justice Department official, Jamie Gorelick (York, 2006). 


\section{GENEROUSLY ACCEPTED ACCOUTING BONUSES}

In its report, OFHEO accused the mortgage-finance giant of a wide range of improper accounting practices including at least one instance in which executives delayed expenses in an apparent effort to hit their bonus targets. OFHEO Report stated that, during the period under investigation, Raines and his management team, "grossly overstated Fannie Mae's earnings - to the tune of $\$ 10.6$ billion - for the purpose of paying themselves big bonuses. By deliberately and intentionally manipulating accounting to hit earnings targets, senior management maximized bonuses and other executive compensation they received, at the expense of shareholders" (York, 2006). OFHEO Report mentioned that, "its findings raise concerns regarding the validity of previously reported financial results, the adequacy of regulatory capital, the quality of management supervision, and the overall safety and soundness of the company" (Haggerty, et. al., 2004).

The OFHEO Report included the following items in Fannie Mae's improper accounting, (Haggerty, et. al., 2004):

- $\quad$ Applying accounting methods and practices that did not comply with the Generally Accepted Accounting Principles (GAAP) to the company's derivatives transactions and hedging.

- Using a "cookie jar" of reserves to improperly delay recognizing income so that it can be used to enhance results in later periods.

- Tolerating what it called "internal control deficiencies".

- Maintaining a corporate culture that emphasized stable earnings at the expense of accurate financial disclosures.

The investigation also revealed that Fannie Mae's accounting for expenses pertaining to its core business of buying mortgages, "was sometimes producing bizarre results. Occasionally, costs that should have been spread over 10 to 15 years were being expensed so rapidly that they were getting amortized in as little as seven months. At other times, expenses did not get amortized at all" (McKinnon, 2004). There was another huge problem that confronted Fannie and probably, Freddie too. In 19998, Financial Accounting Standards Board issued Financial Accounting Standard \#133 which "requires Fannie, Freddie and other companies to record in their earnings the fluctuating values of the options and other derivative contracts they use to hedge interest rate risks, the result, both Fannie and Freddie knew, would be choppier earnings (Haggerty and McKinnon, 2004). Serious irregularities were also detected in Fannie's hedge accounting where requirements under Financial Accounting Standard 133 for hedge accounting were repeatedly violated. If the SEC concludes that Fannie did not qualify for the hedge accounting, Fannie could be forced to record billions of dollars of previously unrecognized losses (Weil and McKinnon, 2004).

\section{A CULTURE OF CORRUPTION AND ARROGANCE}

OFHEO's investigation revealed the existence of an "arrogant and unethical culture" at Fannie. The regulators found an environment where the ends justified the means. Senior management manipulated accounting, reaped maximum, undeserved bonuses, and prevented the rest of the world from knowing. They co-opted their auditors and stonewalled the OFHEO (Mokhiber, 2006). OFHEO report specifically mentioned that, "Fannie sometimes disregarded official accounting guidance, a practice that sheds some light on the culture and attitude within Fannie - a determination to do things, 'their way"' (Haggerty and McKinnon, Sep 24, 2004, p.12).

The OFHEO Report found that Fannie reported extremely smooth profit growth and hit announced targets precisely each quarter. Those illusions were deliberate and systematically created by Fannie's senior management with the aid of improper accounting and earnings management. In short, they cooked the books. Furthermore, "when regulators began to catch on to what was happening, Raines and his team then 'sought to interfere' with the OFHEO investigation by trying to get Congress to start up a separate probe of OFHEO. Fannie also lobbied Congress to cut OFHEO funds unless it got rid off the top officials in charge of investigating Fannie" (York, 2006). Representative Baker (2004) aptly commented that Fannie provides a lesson when, "a company, Frankenstein-like, seemingly grown so powerful that it can intimidate and arrogantly flout all accountability to the very government that created it" (Baker, 2004). 


\section{EPS IS THE MANTRA}

The Report also found that when Raines returned to Fannie in 1998 as its CEO, he became obsessed propping up Fannie's Earnings Per Share (EPS) "even if he had to use creative accounting to make it happen" (York, 2006). Raines set a series of increasingly higher EPS targets, when met, would trigger huge bonuses for the executive team. Many times, these bonuses far surpassed their regular salaries. According to York (2006), Raines announced a new goal in 1999 to double the EPS of Fannie from $\$ 3.23$ to $\$ 6.46$ in five years. From then on, reaching the new EPS goal became Fannie's reason for existence. \$6.46 EPS became the corporate MANTRA. OFHEO Report itself quotes from a speech given by Fannie's head of Office of Auditing, Rajappa to his top managers:

By now every one of you must have 6.46 branded in your brains. You must be able to say it in your sleep, you must be able to recite it forwards and backwards, you must have raging fire in your belly that burns away all doubts, you must live breathe and dream 6.46 you must be obsessed on 6,46... After all, thanks to Frank, we all have a lot of money riding on it (York, 2006).

It worked and Fannie met its EPS goals. Raines rewarded his top executives - and most of all himself - with unheard of amounts of money. Raines salary was never over $\$ 1$ million but his total compensation grew from $\$ \$ 6,8$ million in 1998 to $\$ 8.52 \mathrm{ml}$. In 1999 , to $\$ 13.89 \mathrm{ml}$. in 2000 , to $\$ 18.86 \mathrm{ml}$. in 2001 , to $\$ 18.20$ in 2002 , to $\$ 24.15 \mathrm{ml}$. in 2004 , all on the basis of target EPS. Investigators found that of the total $\$ 90.12$ million paid to Raines in the 6-year period, over \$52 million came from EPS bonuses (York, 2006).

\section{CONCLUSION}

Frank Raines was forced out of Fannie in 2004. A settlement deal was announced by OFHEO in May 2006, whereby, Fannie Mae will pay fines totaling $\$ 400$ million to settle OFHEO and SEC charges of improper accounting. Fannie Mae finally submitted its restatement of incorrect accounting. In December, Fannie Mae announced that it overstated its income between 2001 and 2004 by $\$ 6.3$ billion. Fannie still has to file its financial results for 2005 and 2006. The US Attorney-General's Office had advised Fannie Mae that it was discontinuing its investigation of Fannie Mae accounting and would not file charges. The US Department of Justice also ended its investigation into Fannie Mae, accounting.

The implicit Federal Government guarantee of Fannie Mae and Freddie Mac and the companies' unique size and structure are considered to be posing a systemic risk to the country's entire financial system (Greenspan, 2004). Due to this guarantee, their creditors, and the market in general, are not inclined to monitor their activities rigorously. Some experts have called for complete privatization of these companies. Others suggested for imposition of limits on the mortgage loans. Some legislative measures were introduced in Congress in 2003 to increase the safety-and soundness regulatory oversight measures by either the existing agencies (OFHEO) or by creating a new, independent agency.

\section{SUGGESTIONS FOR FUTURE RESEARCH}

The process of restatement of Fannie Mae's financial statements is yet to be completed. Further research is needed to investigate the total impact of the accounting improprieties at Fannie Mae on its restatement of its financial statements. Further research is also needed to investigate the impact of any privatization efforts, any loan limits that may be imposed and any legislation that would be enacted regarding the future financial structurs of Fannie Mae and Freddie Mac. 


\section{REFERENCES}

1. $\quad$ Baker, Richard H. (2004). Fannie Hits Bottom, Wall Street Journal, October 6, 2004, p. A-18.

2. Carnell, Richard S. (2004). Improving The Regulation of Fannie Mae, Freddie Mac, and The Federal Home Loan Banks, Statement before the Committee on Banking, Housing, and Urban Affairs, U. S. Senate, February 10, 2004, available at: http://banking.senate.gov/

3. Falcon, Armando Jr. (2005). Adult Supervision, Wall Street Journal, October 11, 2005, p. A-16.

4. Frame, Scott W. and Lawrence J. White (2005). Fussing and Fuming Over Fannie and Freddie: How Much Smoke, How Much Fire? Journal Of Economic Perspectives, 19, Spring 2005, pp. 159-184.

5. Greenspan, Alan (2004). Testimony Before the Committee on Housing and Urban Affairs, U. S. Senate, www.federalreserve.gov/boarddocs/testmony/2004/20040224/default.htm

6. Haggerty, James, R. and J. D. McKinnon (2004). In Fannie Mae Probe, Watch Dog Has, Started To Show Its Teeth, Wall Street Journal, September 27, 2004, PP. A-1, 8.

7. Haggerty, James R. and John D. McKinnon (2004). Fannie Mae Ousters Might Come, Wall Street Journal, September 24, 2004, p.A-12.

8. Haggerty, James, R., John D. McKinnon, and Dawn Kopecki (2004). Regulators Detail A Wide Range Of Accounting Problems At Fannie, Wall Street Journal, September 23, 2004, PP. A- 1, 6.

9. McKinnon, John, D. (2004). Fannie Aides Voiced Concerns, Wall Street Journal, September 24, 2004, P. C4.

10. Mokhiber, Russel (2006). Fannie Mae: Unethical, Multinational Monitor, May/June, 2006, P.53.

11. Weil, Jonathan, and John D. McKinnon (2004). Fannie Seeks An Ally In SEC, Wall Street Journal, October 12, 2004, P. C-1.

12. White, Lawrence J. (2005). On Truly Privatizing Fannie Mae and Freddie Mac: Why It's Important And How To Do It? Housing Finance International, December 2005, pp. 13-19.

13. York, Byron (2006). Funny Business At Fannie Mae, National Review, June 19, 2006, pp. 22-24.

\section{NOTES}




\section{NOTES}

